Original Articles

\title{
Brain as a target organ of climate events: Environmental induced biochemical changes in three marine fish species
}

\author{
R. Vieira ${ }^{\mathrm{a}}$, S.M. Marques ${ }^{\mathrm{a}}$, J.M. Neto ${ }^{\mathrm{b}}$, P. Barría ${ }^{\mathrm{b}}$, J.C. Marques ${ }^{\mathrm{b}}$, F.J.M. Gonçalves ${ }^{\mathrm{a}}$, \\ A.M.M. Gonçalves ${ }^{\mathrm{a}, \mathrm{b}, *}$ \\ a Department of Biology and CESAM, University of Aveiro, 3810-193 Aveiro, Portugal \\ ${ }^{\mathbf{b}}$ MARE (Marine and Environmental Sciences Centre), Department of Life Sciences, Faculty of Sciences and Technology, University of Coimbra, 3004-517 Coimbra, \\ Portugal
}

\section{A R T I C L E IN F O}

\section{Keywords:}

Brain

Antioxidant responses

Temporal variability

Flood

Drought

Marine fish species

Mondego estuary

\begin{abstract}
A B S T R A C T
The present study aims to examine physiological and biochemical response of three commercial fish species (Dicentrarchus labrax; Platichthys flesus and Solea solea), over contrasting environmental dynamics: an extremely dry (2012) and flood (2014) years, in a shallow temperate southern European estuary, the Mondego Estuary (Portugal). Physiological and biochemical biomarkers were evaluated by a principal component analysis (PCA), which allowed to conclude that severe climatic events affected the set of fish species analyzed, revealing two distinct annual brain antioxidant responses. The drought episode affected the physiological state of the organisms, as well as increased brain antioxidant potential, strongly associated with fluctuations in environmental drivers (salinity and dissolved oxygen), however, ROS have not been effectively neutralized by antioxidant defence system causing lipid peroxidation. During flood episode was stated a general depletion of the antioxidant potential in the analyzed fish species, affected by interactions with chemical compounds, increased by a combination of high precipitation and associated runoff, probably, increasing nutrient and contaminant load at the Mondego estuary. Nevertheless, lipid peroxidation remained low, related to the action of non-enzymatic antioxidants, since that the studied fish species had optimal physiological status and high nutritive reserves. According to the present work we consider that brain enzymatic depletion may be organ-specific, looking to the greater vulnerability of brain's proteins to degradation compared to lipids. The role of enzymatic mobilization on fish brains is not extensively yet known, but our results suggest that brain seems to be metabolic sensitive to salinity and dissolved oxygen fluctuations. This is the first approach made to evaluate the physiological and biochemical responses of the brain of aquatic organisms' to extreme climatic events and to establish reference values to determine the effects of extreme climate events to aquatic species.
\end{abstract}

\section{Introduction}

In a world experiencing global climate change, the frequency of extreme weather events, such as droughts and periods of flood, appears to be increasing, clearly contributing to the decline in the quality of aquatic systems (IPCC, 2007).

Abiotic (e.g. temperature, salinity, dissolved oxygen, runoff, level of organic matter, etc.) and biotic factors (feeding, reproduction, age, parasitism, etc.) fluctuate throughout the year influenced by extreme climatic events (Hooper et al., 2012). Environmental factors modulate the biology of aquatic organisms, changing the bioavailability of contaminants and the chemical interactivity of them that may increase their toxicity when compared to the action of each compound alone in the aquatic system, especially in estuarine ecosystems with high retention time (Sheehan and Power, 1999).

Reactive oxygen species (ROS) are a non-viable part of aerobic life, resulting in oxidative stress if ROS generation prevails over antioxidant capacity (Lushchak, 2011). ROS cause damage to cellular proteins, lipids and nucleic acids, often leading to injury of organs (Lushchak, 2011). In order to protect against oxidative stress, organisms develop their antioxidant defence system consisting of low molecular weight metabolites (tocopherol, ascorbic acid, glutathione) and higher molecular weight proteins including antioxidant enzymes such as glutathione peroxidase (GPx), glutathione S-transferase (GST) and

\footnotetext{
* Corresponding author at: MARE (Marine and Environmental Sciences Centre), Department of Life Sciences, Faculty of Sciences and Technology, University of Coimbra, 3004-517 Coimbra, Portugal; Department of Biology and CESAM, University of Aveiro, 3810-193 Aveiro, Portugal.

E-mail addresses: amgoncalves@uc.pt, anamartagoncalves@ua.pt (A.M.M. Gonçalves).
} 


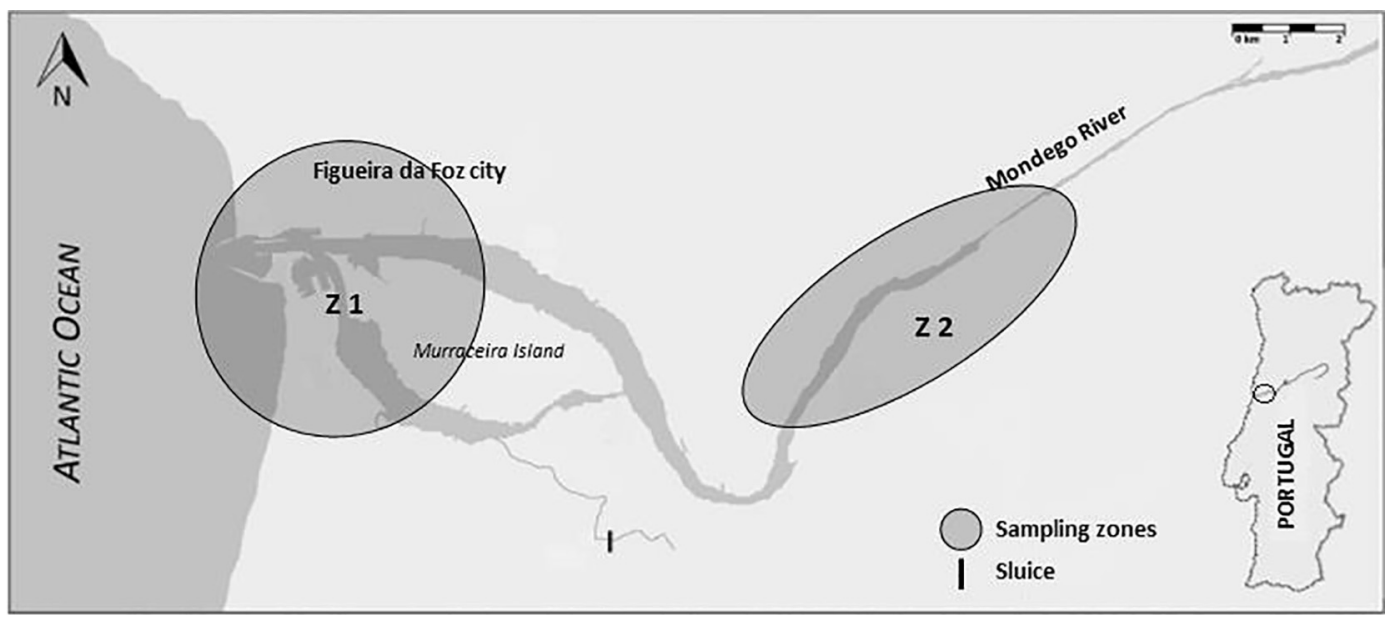

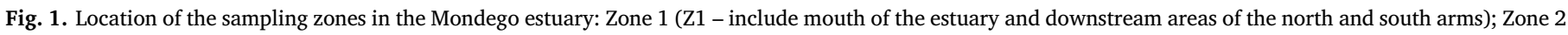
(Z2 - include medium and upstream areas of the north arm).

glutathione reductase (GR), which are used globally as early warning signals of environmental stress conditions (Hellou et al., 2012). Lipid peroxidation (LPO) has been described as the major contributor to the loss of cellular function under oxidative stress, and has been usually indicated by Thiobarbituric acid reactive substances (TBARS) measurements in fish (Van der Oost et al., 2003). Temporal variations of antioxidant defences may affect the protection level of organisms and make it difficult to distinguish between the effects of pollutants and the effects of other environmental factors (Pain et al., 2007). Consequently, it is greatly important to determine the normal range of biomarkers variability in order to propose useful environmental diagnostic tools (Lushchak, 2011).

Recently, some studies have shown that the brain is a highly sensitive organ to determine oxidative stress in both fish and humans (e.g. Huang et al., 2008; Ferraro et al., 2009), associated with the decline of its richness in PUFA-n3 fatty acid (Dringen, 2000). Brain is one of the most active and sensitive metabolic organs to be altered by a wide variety of factors (Soengas and Aldegunde, 2002). Therefore, more research is necessary to verify induced oxidative damages, especially in neural tissues due to the importance of their crucial functions for the organisms' survival (Birnie-Gauvin et al., 2017). The limited number of published studies are the main reason to the scarce knowledge about the threat of oxidative stress in the fish brain, with most of them being laboratory experiments, involving the injection of toxic substances (Hellou et al., 2012). In this context, more information about the antioxidant system in the fish brain is needed in order to evaluate the susceptibility to suffer neurotoxicity, considering the crucial role of environmental factors (Pain et al., 2007). In addition to the accumulation of toxic substances, it is essential to include the temporal factor as an influence on the variation of responses to oxidative stress (Hooper et al., 2012). Measurements of biomarkers responsiveness in fish have a good potential to integrate environmental monitoring programs (Van der Oost et al., 2003). The complexity of these variables added to extreme weather events should be taken into account when interpreting the results on the field and in laboratory experiments (Hellou et al., 2012; Hooper et al., 2012).

Dicentrarchus labrax and two flatfish species, Platichthys flesus and Solea solea, were chosen for this study, because of their high economic and commercial interest, being the most abundant and representative species of the Atlantic and Mediterranean coasts, occupying a high trophic position and occurring in the most European estuaries, including the Mondego estuary. These species have been commonly used in many field and laboratory studies, proving to be viable and sensitive to environmental anomalies (Kopecka \& Pempkowiak, 2008; Kleinkauf et al., 2004; Oliva et al., 2012). Extreme climatic events have been verified in the last decades worldwide, Portugal not being an exception (Gonçalves et al., 2017), with ecological impacts to aquatic communities (e.g. Gonçalves et al., 2012; Grilo et al., 2011).

Since it is crucial to determine and evaluate the physiological and biochemical responses of organisms under the influence of extreme climatic events, the main objectives of this work are to: 1 ) determine the physiological and biochemical responses in brain samples from the three fish species collected at the Mondego estuary; 2) extract the causal influences in variability on selected biochemical and physiological markers; 3) compare the responsiveness of the three commercial fish species and infer about the potential use of the brain and the selected battery of biomarkers to assess the specific response to climate events, contributing to the elimination of gaps in biomonitoring studies in estuarine and coastal systems.

\section{Materials and methods}

\subsection{Study site}

The Mondego estuary, situated in a warm temperate region on the Atlantic coast of Portugal $\left(40^{\circ} 08^{\prime} \mathrm{N}, 8^{\circ} 50^{\prime} \mathrm{W}\right)$, is a small estuary of $8.6 \mathrm{~km}^{2}$, comprising two arms, north and south, separated by an island, and at from $7 \mathrm{~km}$ from shore that join again near the mouth (Fig. 1). The north arm is deeper (5-10 $\mathrm{m}$ during high tide, tidal range $2-3 \mathrm{~m}$ ), highly hydrodynamic, is a main navigation channel and hosts the Figueira da Foz harbour. The south arm is shallower (2-4 m during high tide, tidal range 1-3 $\mathrm{m}$ ) and is characterized by large areas of exposed intertidal flats during low tide, with higher residence times and is almost silted over in the upstream areas. The mouth of the estuary depth ranges from 8 to $13 \mathrm{~m}$, and this area is influenced by both river flow and neritic waters. Most of the river freshwater flow enter via the north arm and a small freshwater input is carried via the southern arm through the Pranto River, a small tributary system regulated by a sluice according to water needs in the surrounding rice fields. Previous studies demonstrated that singular environmental factors provide a large variety of aquatic habitats for species, mainly due to salinity gradient (Gonçalves et al., 2012).

The main environmental pressures in the Mondego estuary are: dredging and shipping in the north arm, raw sewage disposal and high nutrient input from agricultural and fish farms in upstream areas of the estuary. Combined with a high water residence time, this has led to an eutrophication process over the past two decades (Dolbeth et al., 2013). The system has been recovering from this particular eutrophication scenario since early 1990's, showing nowadays, a significant improvement in water quality and own faunal composition (e.g. Dolbeth et al., 


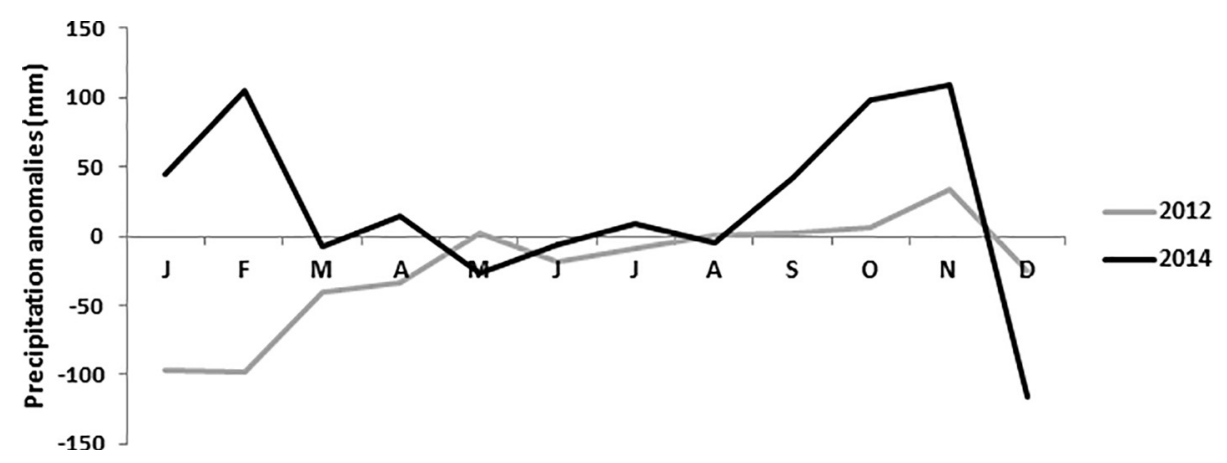

Fig. 2. Monthly precipitation anomalies ( $\mathrm{mm}$ ) in the Mondego estuary during the study period (2012-2014) according to monthly average of 1971-2000, represented as null value. The precipitation values were recorded daily during the sampling years, organized in monthly average and compared to monthly average of 1971-2000. The data was supplied for Agência Portuguesa do Ambiente (APA).
2013). In 2006, re-opened the upstream separation between the two arms, with an increase of the flow and a reduction of the water residence time (e.g. Veríssimo et al., 2012). Previous studies indicated low to moderate levels of metals (Coelho et al., 2006), PCBs (Baptista et al., 2013) and dioxin like PCDD/Fs (Nunes et al., 2011) in the watersediment fraction of Mondego estuary. In the same instance, Martinho et al. (2015) observed a decreasing trend in total anthropogenic pressure between 2005 and 2012, reflecting mainly a decline in agriculture occupied area, number of industries and population density in the watershed over the last decade, pointing a constant increase in ecological quality of the estuarine ecosystem, assessed by fish component.

\subsection{Biological and hydrological data}

Sampling in spring and autumn seasons was performed, between two distinct severe weather events (drought - May and December 2012; flood - June and October 2014), during high tides, at two zones distributed throughout both arms, along the salinity gradient of the Mondego estuary (Fig. 1). The selected sampling zones covered the majority of the estuarine area, representing several habitats and salinity ranges, providing a good overview of the whole fish studied species from the Mondego estuary. The zone 1 (Z1) covers the mouth and the final stage of the north and south arms, is mostly influenced by neritic waters, more hydrodynamic and with high water residence time than zone 2 (Z2) that includes the medium and upstream northern areas of the estuary highly influenced by freshwater flow. Sampling took place using a $2 \mathrm{~m}$ beam trawl with one tickler chain and a stretched mesh size of $5 \mathrm{~mm}$ in the cod end. Thirty replicate hauls were made per year, taking into account the zones and seasons (haul duration 10/15 min). Tow location and distance were determined with a GPS. Covering two sampled areas representative of the entire estuarine system, 112 individuals were selected, maintained in cold bags during their transport to the laboratory and distributed by spring $2012(\mathrm{n}=30)$; autumn 2012 ( $n=30)$; spring $2014(\mathrm{n}=23)$; autumn $2014(\mathrm{n}=29)$. The common sole (S. solea) was not collected in zone 2, because their distribution within the Mondego estuary is restricted to downstream areas (zone 1) (e.g. Martinho et al., 2007). The fish species were selected to ensure standardization of age and size as possible ( $D$. labrax: $12.62 \mathrm{~cm} \pm 2.11 \mathrm{~cm}$; P. flesus $14.40 \mathrm{~cm} \pm 2.27 \mathrm{~cm}$, mean length \pm SD), although slightly larger at the common sole (S. solea: $17.53 \mathrm{~cm} \pm 3.53 \mathrm{~cm}$ ) were caught. Parasitism activity was not found (data not shown). In the lab, organisms were measured (total length, $1 \mathrm{~mm}$ accuracy), weighed $(0.01 \mathrm{~g}$ precision), and the brain was removed, weighted and stored in $-80{ }^{\circ} \mathrm{C}$ for later biochemical analysis. In parallel to each sampling event, several hydrological parameters were measured in situ: water temperature $\left({ }^{\circ} \mathrm{C}\right)$, salinity $\left(\mathrm{mg} \mathrm{L}^{-1}\right)$, dissolved oxygen concentration ( $\mathrm{mg} \mathrm{L}^{-1}$ ), and $\mathrm{pH}$ using a multi-parameter probe.

The monthly precipitation values were registered at the Soure 13F/ 01G station and acquired from INAG - Instituto da Água (www.snirh. inag.pt). Long-term monthly average precipitation was calculated from data collected at the Soure 13F/01G station from 1971 to 2000.
Freshwater discharge from the Mondego River was also obtained from the INAG station near the mouth of River, for the study period.

\subsection{Environmental characterization}

A consistent drought event characterized the year 2012, revealing an annual total precipitation of $246.1 \mathrm{~mm}$ below the normal climatic value of 1971-2000 (APA, 2013). The highest negative precipitation anomalies were verified in January $(-96.9 \mathrm{~mm})$, February $(-97.9 \mathrm{~mm})$, March $(-40.4 \mathrm{~mm})$ and April $(-33 \mathrm{~mm})$ (Fig. 2), in relation to the climatological pattern to central region of Portugal between 1971 and 2000 (http://snirh.apaambiente.pt). According to Agência Portuguesa do Ambiente (2013), 2012 was the 8th driest year since 1931.

An extreme flood event aroused in 2014, verifying a higher annual total precipitation than the normal climatic of 1971-2000, with a deviation of $+216.1 \mathrm{~mm}$; also attributed the rainiest year of the last 25 years, the month of February was the wettest month of the last 35 years (APA, 2015). The positive anomalies of January $(+44.3 \mathrm{~mm})$; February $(+105 \mathrm{~mm})$; October $(+98.2 \mathrm{~mm})$ and November $(+109.4 \mathrm{~mm}$ ) (Fig. 2) were recorded for the Mondego estuary basin, and higher than the normal climatic of 1971-2000 for central Portugal (http://snirh.apaambiente.pt). According to the Portuguese Weather Institute (http://web.meteo.pt/pt/clima/clima.jsp) in the last decade drastic differences have been recorded, compared to the general climate patterns for the period of 1971-2000 (Gonçalves et al., 2012).

Freshwater runoff was significantly higher in flood (2014) than in drought (2012) episode (Fig. 3), clearly influenced by precipitation regimes showing highly significant positive correlation between these parameters $(r=0.77, \mathrm{p}<0.001)$.

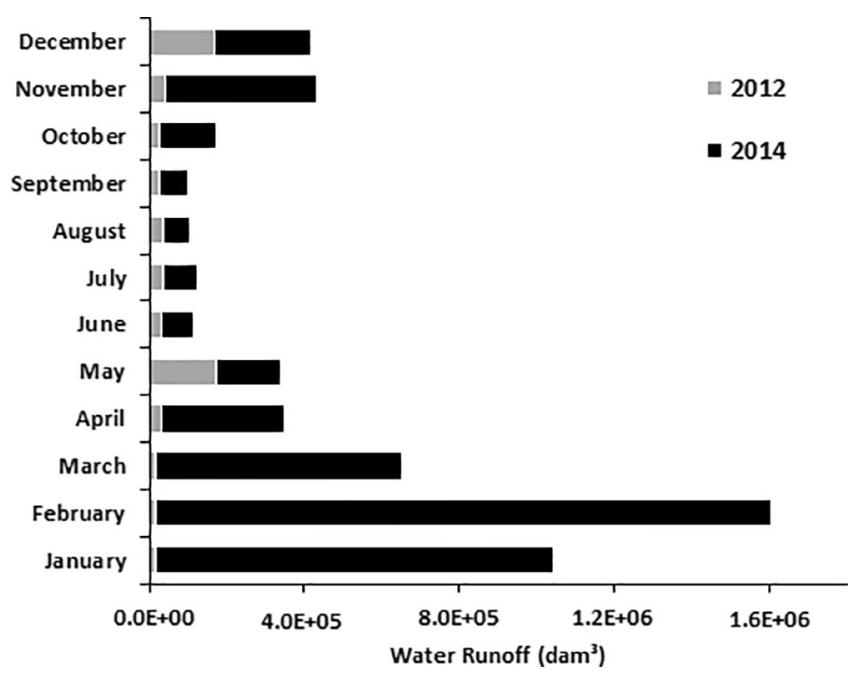

Fig. 3. Monthly runoff $\left(\mathrm{dam}^{3}\right)$ during the study period (2012-2014), in the Mondego estuary area. 
Table 1

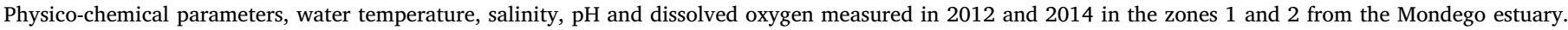
Means \pm standard errors.

\begin{tabular}{|c|c|c|c|c|c|c|c|c|}
\hline \multirow[t]{3}{*}{ Parameters } & \multicolumn{4}{|l|}{2012} & \multicolumn{4}{|l|}{2014} \\
\hline & \multicolumn{2}{|l|}{ Autmun } & \multicolumn{2}{|l|}{ Spring } & \multicolumn{2}{|l|}{ Autumn } & \multicolumn{2}{|l|}{ Spring } \\
\hline & zone 1 & zone 2 & zone 1 & zone 2 & zone 1 & zone 2 & zone 1 & zone 2 \\
\hline \multirow[t]{2}{*}{ Temp $\left({ }^{\circ} \mathrm{C}\right)$} & 13.93 & 11.65 & 19.53 & 16.75 & 18.70 & 18.25 & 18.03 & 20.00 \\
\hline & {$[0.22]$} & {$[0.67]$} & [1.33] & [0.32] & {$[0.26]$} & {$[0.32]$} & [1.90] & {$[0.21]$} \\
\hline \multirow[t]{2}{*}{ Sal $\left(\mathrm{mg} \mathrm{l}^{-1}\right)$} & 34.46 & 22.70 & 29.40 & 4.68 & 22.01 & 0.155 & 24.8 & 3.92 \\
\hline & [1.78] & [7.65] & [2.63] & {$[0.011]$} & [0.69] & [0.025] & [3.25] & [2.77] \\
\hline \multirow[t]{2}{*}{$\mathrm{pH}$} & 7.89 & 7.13 & 7.93 & 7.67 & 7.24 & 8.06 & 7.72 & 8.07 \\
\hline & [0.075] & {$[0.10]$} & {$[0.71]$} & [0.018] & {$[0.15]$} & {$[0.21]$} & {$[0.10]$} & [0.33] \\
\hline \multirow[t]{2}{*}{$\mathrm{O}_{2}$} & 6.73 & 7.08 & 6.96 & 7.10 & 10.16 & 10.71 & 7.83 & 8.07 \\
\hline & [0.083] & {$[0.05]$} & {$[0.15]$} & [0.035] & {$[0.082]$} & {$[0.11]$} & {$[0.08]$} & [0.035] \\
\hline
\end{tabular}

In general, the two distinct severe weather events reflected different hydrological parameters in the Mondego estuary, with the exception of $\mathrm{pH}$, which ranged from 7 to 8 in two sampling periods. Salinity levels was significantly higher in the drought year of 2012 in whole estuarine area (Table 1), especially noted in autumn Z1 $\left(34.46 \mathrm{mg} \mathrm{L}^{-1}\right)$ and Z2 $\left(22.70 \mathrm{mg} \mathrm{L}^{-1}\right)$, compared with the same season-zones in the flood sampling period $\left(22.01 \mathrm{mg} \mathrm{L}^{-1}\right)$ and $\left(0.16 \mathrm{mg} \mathrm{L}^{-1}\right)$, respectively. At the flood event salinity values recorded an approach from the standard salinity gradient typical from this estuarine system (see Gonçalves et al., 2012). Dissolved oxygen showed an inverse tendency, with the lowest values recorded in the Autumn - Z1 $\left(6.73 \mathrm{mg} \mathrm{L}^{-1}\right)$; Z2 $(7.08 \mathrm{mg}$ $\left.\mathrm{L}^{-1}\right)$ and Spring $-\mathrm{Z} 1\left(6.96 \mathrm{mg} \mathrm{L}^{-1}\right) ; \mathrm{Z} 2-\left(7.10 \mathrm{mg} \mathrm{L}^{-1}\right)$ of the drought sampling period, compared to the highest values in Autumn - Z1 $\left(10.16 \mathrm{mg}^{-1} \mathrm{~L}\right) ; \mathrm{Z} 2\left(10.71 \mathrm{mg} \mathrm{L}^{-1}\right)$ and Spring - Z1 $\left(7.83 \mathrm{mg} \mathrm{L}^{-1}\right)$ and $\mathrm{Z} 2\left(8.07 \mathrm{mg} \mathrm{L}^{-1}\right)$ levels registered in the flood event. Water temperature floated without apparently a high degree of severity with the maximum value registered in the spring of flood sampling period $\left(20.00{ }^{\circ} \mathrm{C}\right)$ and the minimum value recorded in autumn of drought year event $\left(11.65^{\circ} \mathrm{C}\right)$ (Table 1$)$.

\subsection{Gross morphometric indices}

To analyze the first impact of climatic events on the fish physiological condition, gross morphometric indices based on length-weight data of all fish species sampled were measured:

Condition factor (K) using the formula:

$\mathbf{K}=100\left(\mathbf{W} / \mathbf{L}^{3}\right)$

Liver condition ( $\mathrm{K}$ liver) using the formula:

K liver $=100\left(\mathrm{Lw} / \mathbf{L}^{3}\right)$

Hepatosomatic index (HSI) was calculated using the formula (Van der Oost et al., 2003):

$\mathrm{HSI}=\mathbf{1 0 0}(\mathrm{Lw} / \mathrm{W})$

where W represents the total weight $(\mathrm{g})$; L the total length $(\mathrm{cm})$ and Lw the liver weight $(\mathrm{g})$.

\subsection{Biomarker measurements}

\subsubsection{Homogenate}

Brain mass from each individual fish was homogenized individually in ice-cold phosphate buffer $(50 \mathrm{mM}, \mathrm{pH}=7.0$ with $0.1 \%$ TRITON X100). The homogenate was centrifuged at $15,000 \mathrm{~g}$ for $10 \mathrm{~min}$ at $4{ }^{\circ} \mathrm{C}$ (Eppendorf 5804R, Eppendorf AG; Hamburg, Germany) and supernatant fluid stored for determination of protein and enzymes activity using spectrometry method.

\subsubsection{Protein}

The protein concentration used for a number of biomarkers measurements (GR, GST, GPx and LPO), was determined using Bradford (1976) method with bovine serum albumin (BSA, Sigma) as a standard. All protein measurements were carried out using a microplate reader (Genios, TECAN) recorded at $595 \mathrm{~nm}$.

\subsubsection{Glutathione reductase (GR)}

Glutathione reductase (EC 1.8.1.7) activity was determined by spectrophotometry, according the protocol of Carlberg and Mannervik (1985). In this assay the GRed mediated oxidation of NADPH was monitored at $340 \mathrm{~nm}$ (molar extinction coefficient of $6.22 \mathrm{mM}^{-1} \mathrm{~cm}^{-1}$ ).

\subsubsection{Glutathione S-transferase (GST)}

Glutathione S-transferase (EC 2.5.1.18) activity was assayed at $340 \mathrm{~nm}$ by measuring the increase in absorbance using 1-chloro-2, 4dinitrobenzene (CDNB) as the substrate according to Habig et al. (1974). The assay was carried out with a $0.2 \mathrm{ml}$ mixture of phosphate buffer (100 mM, pH 6.5), CDNB (60 mM) and GSH (10 mM). GST activity was calculated as nmol CDNB conjugate formed $\mathrm{min}^{-1} \mathrm{mg}^{-1}$ protein using a molar extinction coefficient of $9.6 \mathrm{mM}^{-1} \mathrm{~cm}^{-1}$.

\subsubsection{Glutathione peroxidase (GPx)}

Glutathione peroxidase (EC 1.11.1.9) activity was determined according to the method described by Flohé and Günzler (1984). The assay mixture consisted of $0.09 \mathrm{ml}$ phosphate buffer ( $100 \mathrm{mM}, \mathrm{pH} 7.0), 0.03 \mathrm{ml} \mathrm{Na} 2$ EDTA $(10 \mathrm{mM}), 0.03 \mathrm{ml}$ sodium azide $(10 \mathrm{mM}), 0.03 \mathrm{ml} \mathrm{GR}(2.4 \mathrm{IU} / \mathrm{ml}), 0.03 \mathrm{ml}$ GSH $(10 \mathrm{mM}), 0.03 \mathrm{ml}$ NADPH $(1.5 \mathrm{mM}), 0.03 \mathrm{ml}$ Cumene $(7 \mathrm{mM})$. Oxidation of NADPH was recorded at $340 \mathrm{~nm}$, and GPx activity was calculated in terms of nmol NADPH oxidized $\mathrm{min}^{-1} \mathrm{mg}^{-1}$ protein using a molar extinction coefficient of $6.2 \mathrm{mM}^{-1} \mathrm{~cm}^{-1}$.

\subsubsection{Lipid peroxidation ( $L P O)$}

LPO was determined in the previously prepared homogenate as adapted by Correia et al. (2003). Briefly, this methodology is based on the reaction of lipid peroxidation by-products, such as malondialdehyde (MDA), with 2-thiobarbituric acid (TBA). The amount of TBARS was measured spectrophotometrically as a single determination, at a wavelength of $535 \mathrm{~nm}$ (molar extinction coefficient of $1.56 \times 10^{6} \mathrm{M}^{-1} \mathrm{~cm}^{-1}$ ) and the rate of LPO was expressed in nmol of thiobarbituric acid reactive substances (TBARS) formed $\mathrm{mg}^{-1}$ of fresh tissue.

\subsection{Statistical analysis}

Distinct data sets were built (biomarker and physiological profile), separately normalized and analyzed with Principal Component Analysis (PCA), which reduced the multidimensional data matrices to interpretable bi-dimensional plots that explain the highest proportion of variation in the data (following Ter Braak, 1995). Two-way analysis of variance (ANOVA) 


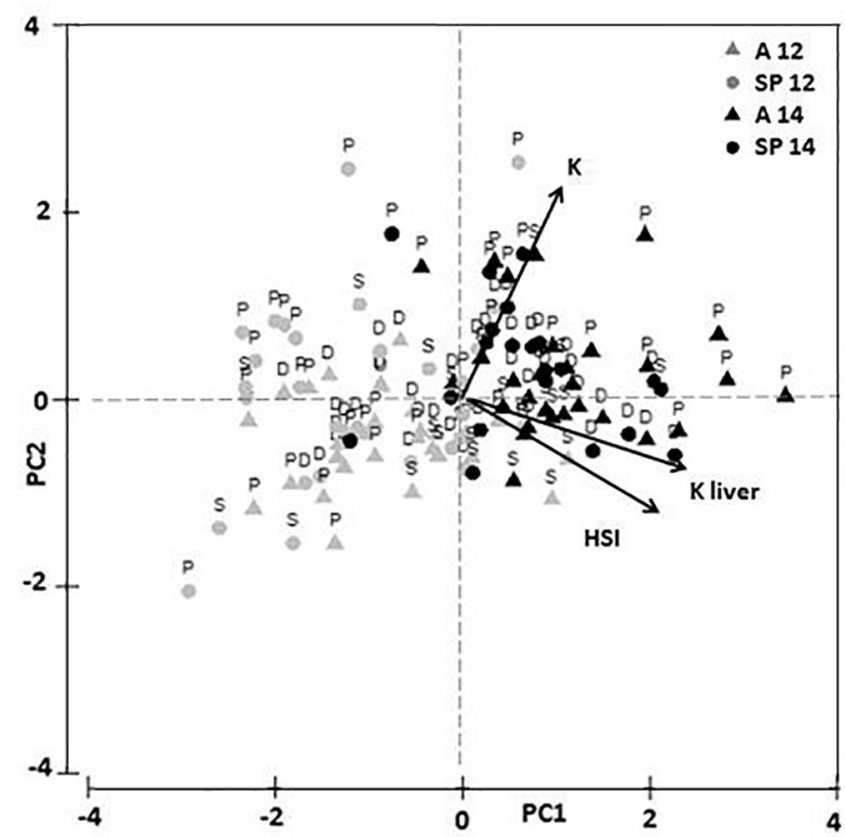

Fig. 4. PCA biplot of fish scores (D. labrax - D; P. flesus - P; S. solea - S) from two distinct sampling periods (2012-2014) along two seasons (autumn - A; spring - SP), illustrating their variation according to physiological state (B). Triangles represent autumn and circles spring samples. Grey symbols represent 2012, and black symbols represent 2014 samples.

was performed on the PCA sample score to assess seasonal (season-variable) and temporal (year-variable) differences in the datasets, allowing an overall appraisal of the sources of variation in the physiological and biochemical patterns of the studied fish species. Similar approaches have been described in the literature for other physiological and biochemical data matrices. Spearman rank correlation factor $(r)$ was used to test significant relations between environmental drivers, antioxidant defenses and LPO. A significance level of 0.05 was considered in all test procedures. Multivariate analysis PCA and correlation analysis were conducted using PRIMER-6 Software (Clarke and Gorley, 2006). ANOVAs and graphs were carried out in Minitab 17 (Minitab Inc, State College PA, USA).

\section{Results}

\subsection{Physiological state}

All fish organisms showed lower condition factor (K), liver condition (K liver) and hepatosomatic index (HIS) in drought (2012) compared to flood (2014) (Fig. 4), which means an increase of the relative weight of liver, incremented nutritive reserves, and better condition state at the flood event.

The physiological data set analysis using PCA revealed temporal variability in the physiological state of the organisms mainly related to extreme weather events (Fig. 4) (see variance and F-test of ANOVA applied to PCA scores, Table 2), a minor contribution of the year $\mathrm{x}$ season interaction and a non-significant contribution was stated for the season variable (see effect season and year $\mathrm{x}$ season interaction, Table 2). Two first PCA components were analyzed; PC1 and PC2 explaining $76 \%$ and $23.9 \%$, respectively, and both explained the largest fraction $(99.9 \%)$ of variability for the fish physiological state.

\subsection{Oxidative stress profile}

\subsubsection{Antioxidant responses}

The analysis of the biochemical data set using PCA revealed a temporal significant variance for the three fish species (Fig. 5) (see variance and F test of ANOVA applied to the scores PCA, Table 3). On the other hand, a minor
Table 2

Summary of two-way ANOVA from physiological data set on the fish scores (principal components 1 and 2), showing the degrees of freedom (d.f), variance MS, F-test and corresponding P-value.

\begin{tabular}{llllll}
\hline Physiological state & Source of variation & $d f$ & $M S$ & $F$ & $P$ \\
\hline PC1 & Year & 1 & 119.76 & 98.70 & $<0.001$ \\
& Season & 1 & 0.58 & 0.48 & n.s \\
& Year x Season & 1 & 0.31 & 0.25 & n.s \\
& Residuals & 108 & 1.21 & & \\
PC2 & Year & 1 & 3.93 & 5.98 & 0.016 \\
& Season & 1 & 0.88 & 1.34 & n.s \\
& Year x Season & 1 & 3.38 & 5.14 & 0.025 \\
& Residuals & 108 & 0.66 & & \\
\hline
\end{tabular}

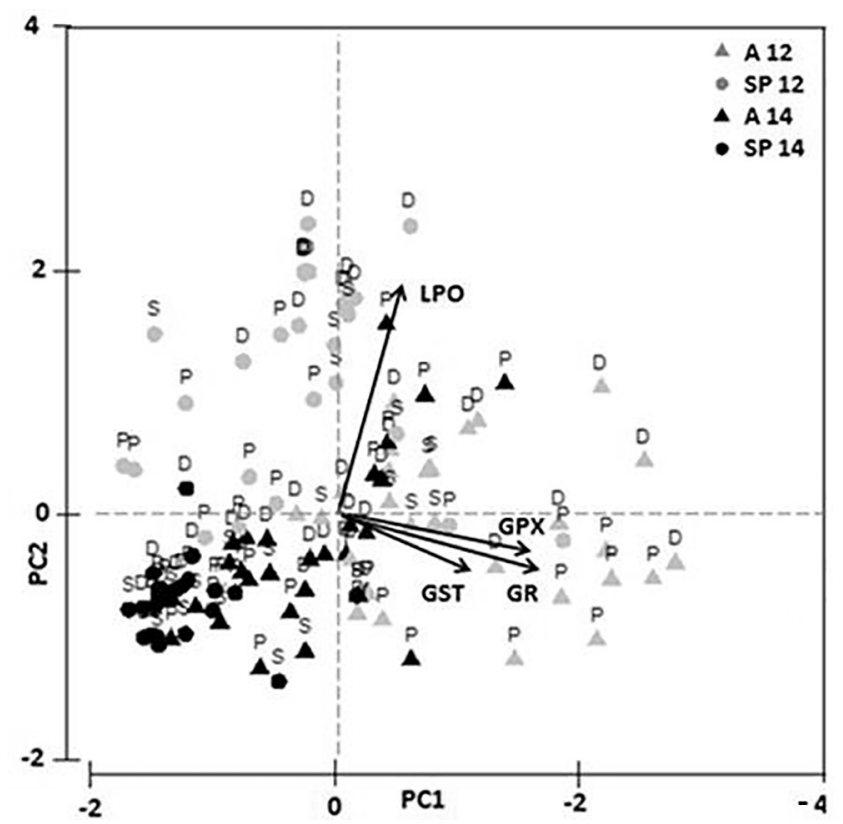

Fig. 5. PCA biplot of fish scores (D. labrax - D; P. flesus - P; S. solea - S) from two distinct sampling periods (2012-2014) along two seasons (autumn - A; spring - SP), illustrating their variation according to biochemical profile (B). Triangles represent autumn and circles spring samples. Grey symbols represent 2012, and black symbols represent 2014 samples.

contribution of variability found in the data set of biomarkers profiles was attributed to the seasonality, and a smaller but still significant contribution was attributed to the interaction variable year $\mathrm{x}$ season (see effect of season and of the interaction variable year $\mathrm{x}$ season, Table 3). It is important to recognize that, contrary to the verified in the data set of the physiological state, the season variable seems to have a certain degree of importance in the variability of the antioxidant responses of the organisms, mainly in the

Table 3

Summary of two-way ANOVA from biochemical data set on the fish scores (principal components 1 and 2), showing the degrees of freedom (d.f), variance MS, F-test and corresponding P-value.

\begin{tabular}{llllll}
\hline Biochemical profile & Source of variation & $d f$ & $M S$ & $F$ & $P$ \\
\hline PC1 & Year & 1 & 55.28 & 55.28 & $<0.001$ \\
& Season & 1 & 47.38 & 47.38 & $<0.001$ \\
& Year x Season & 1 & 4.37 & 4.40 & 0.038 \\
& Residuals & 108 & 0.99 & & \\
PC2 & Year & 1 & 22.96 & 43.58 & $<0.001$ \\
& Season & 1 & 4.45 & 8.44 & 0.004 \\
& Year x Season & 1 & 18.16 & 34.43 & $<0.001$ \\
& Residuals & 108 & 0.53 & &
\end{tabular}



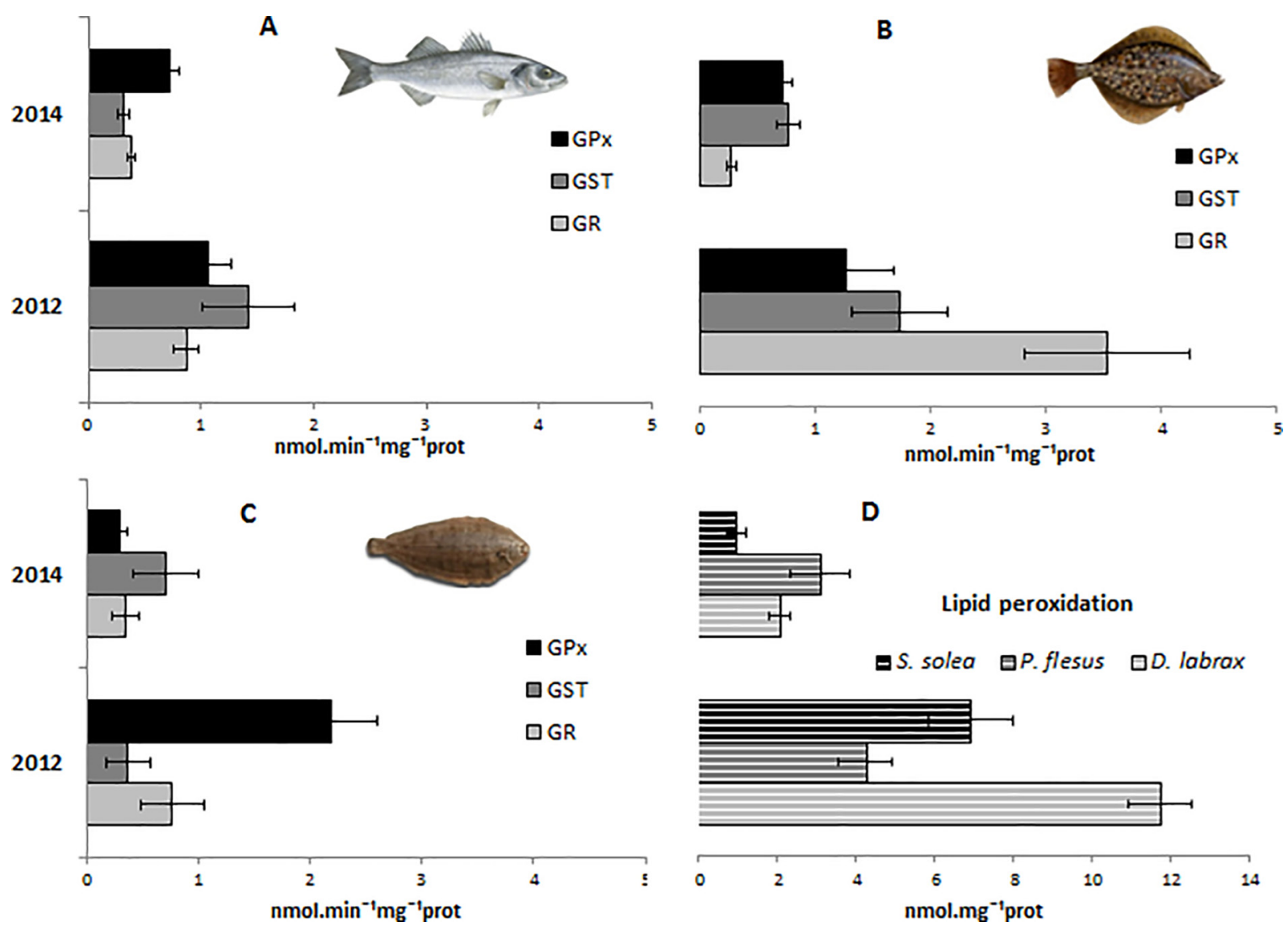

D

Lipid peroxidation

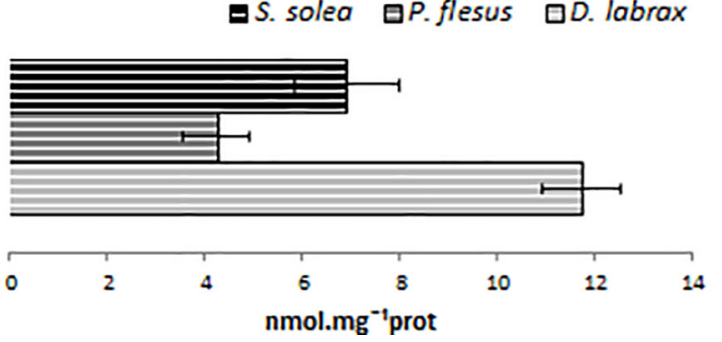

Fig. 6. Representation of the enzymes' activity GR, GST, GPx in the brain of (A) Dicentrarchus labrax, (B) Platichthys flesus, (C) Solea solea, and (D) lipid peroxidation of all studied species, along the two distinct study periods (autumn, spring - 2012 and autumn, spring - 2014).

samples of drought event (Fig. 5). First two PCA components were analyzed, and together they explained $71.2 \%$ of the variability of the biomarker profile, with $48.0 \%$ and $23.2 \%$ for PC1 and PC2, respectively. The same patterns were slightly found between the analysis of biochemical data and the physiological status of the organisms $(r=0.12, p<0.001)$.

Significant decrease in the antioxidant enzyme activities GR, GST and GPx were observed in the brain of the three fish species studied and collected in the flood year (2014), compared to drought episodes (2012) (Fig. 6 A, B, C). However, no significant changes were observed in the enzymatic activities when the three species were compared, highlighting the strong impact of the verified temporal variable, associated with effect of climate event phenomena. Thus, samples of brain fish species captured at flood event displayed decreases in antioxidant responses, similar in percentage terms; GR activity decreased around $57.17 \%, 92.15 \%$ and $54.85 \%$, GPx activity $32.43 \%, 43.58 \%$ and $86.56 \%$, for $D$. labrax, P. flesus and S. solea, respectively. Concerning to GST activity, decreased $78.33 \%$ and $55.40 \%$ in the brain of $D$. labrax and $P$. flesus, respectively; although, there has been an increase of $47.47 \%$ in the activity of this enzyme for $S$. solea.

According to the Spearman rank correlations (Table 4), only significant correlations are presented), GR was positively correlated with GST and GPx. In addition, strong correlations between environmental drivers (salinity and dissolved oxygen) with the activity of antioxidant enzymes were stated (Table 4); GR, GST and GPx activities were positively correlated with salinity, and inversely correlated with dissolved oxygen. It should be noted that the higher antioxidant enzyme activities coincided with the high salinity periods and lower levels of dissolved oxygen, which occurred at drought events; this fact leads to indicate the strong salinities and dissolved oxygen deficiency as enzymatic stimuli in all studied species.

\subsubsection{Peroxidative damage}

Lipid peroxidation levels in the brain of all studied species showed
Table 4

Significant Spearman rank correlations between the studied antioxidant responses in the brain and abiotic factors ( $\mathrm{SAL}$-salinity and $\mathrm{O}_{2}$ - dissolved oxygen). (GPx-glutathione peroxidase, GR-glutathione reductase, GST—glutathione Stransferase, LPO-Lipid peroxidation and n.s-not-significant) $r$-Spearman rank, $P<0.05$.

\begin{tabular}{lllllll}
\hline Variable & GST & GR & GPx & LPO & SAL & $\mathrm{O}_{2}$ \\
\hline GST & \multirow{2}{*}{1} & 0.765 & n.s & 0.410 & 0.575 & -0.219 \\
GR & & 1 & 0.395 & n.s & 0.583 & -0.329 \\
GPx & & & 1 & 0.528 & 0.724 & -0.237 \\
LPO & & & & 1 & n.s & -0.406 \\
SAL & & & & & 1 & 0.720 \\
$\mathrm{O}_{2}$ & & & & & & 1 \\
\hline
\end{tabular}

significant differences among the distinct severe climatic events observed in the years 2012 and 2014 (Fig. 6 D). Peroxidative damage was substantially higher at the drought event than at the flooding year, with decreases in LPO of $82.43 \%, 27.52 \%$ and $86.15 \%$ for D. labrax, P. flesus and $S$. solea, respectively, at the flood episodes. Positive significant Spearman rank correlations were found between LPO and GST, as well as among LPO and GPx (Table 4). Moreover, LPO were also negatively correlated with oxygen dissolved fluctuations (Table 4).

\section{Discussion}

\subsection{Physiology and antioxidant potential}

Our results revealed worse physiological state of the fish species sampled at the drought event compared to the good physiological level observed at the flooding sampled year, clearly showing two different 
physiological effects related to the distinct climate phenomena occurred in the Mondego estuary.

This study is a first approach to evaluate the physiological state of marine fish species under extreme climatic events, even more with a long sampled period composed of two distinct years. In the literature is only widely recognized that the higher levels in these morphometric indices are indicative of good physiological condition and better health (e.g. Lloret et al., 2002; Kopecka and Pempkowiak, 2008), existing some shortcomings regarding the difficulty in assigning reasons for worse physiological state of aquatic organisms, since this may be affected by a great amount of associated factors (Lushchak, 2011). Poor physiological condition observed in fish sampled at drought events seems to be associated with lower food availability and quality, greater interspecific competition and fluctuations in environmental drivers (salinity and dissolved oxygen). Previously, some studies at the Mondego estuary have recognized that at drought events there are a decrease in the fish production (especially evident for $D$. labrax and $P$. flesus), in the order of 15-45\% (Dolbeth et al., 2008) mainly affected by fluctuations in environmental drivers. Similarly, Attrill and Power (2000) observed to Thames estuary, UK, that changes in key benthic species, such as Carcinus maenas and Crangon crangon, modifies the fish community trophic chain during extreme droughts. Baptista et al. (2010) also reported that in drought years, competition seems to increase in the Mondego estuarine area, related to environmental dynamics (e.g. high salinities) contributing to the appearance of new adventitious fish species, consequently decreasing food and habitat resources.

Similar assumptions presented in our study were described by Eastwood and Couture (2002) and Pottinger et al. (2002), indicating food availability, salinity and oxygen fluctuations and signals of contamination as modulator-factors to physiological state of aquatic organisms. Lloret et al. (2002) also pointed out that the worst state in juveniles fish are associated with the exhaustion of energy reserves, making them much more susceptible to environmental drivers (Lloret et al., 2002).

In the present study, the size and age of the individuals are similar, leading to consider the variation-factor "severe climatic event" strictly associated with environmental cues mentioned above, although, it has been universally valid that an index can be more relevant than another for a given fish species, due to the adaptive response to a stress factor, different storage mode of energy reserves, and age.

The absence of seasonal patterns, in the physiological status from analyzed species, is surprisingly interesting because the majority of works reported seasonal variations in field studies, involving gross morphometric indices, highlighting specific chemical pollutants (e.g. OCPs, PCBs and PAHs) in specific seasons, or reproductive events, such as spawning period, to justify these variations (e.g. Nunes et al., 2011). According to our results, it seems that prolonged severe climatic events affect the fish community of the estuary, as a whole, probably disturbing environmental drivers, ecosystem sources and services.

Although, the most of the studies on oxidative stress focuses on the toxicological aspects to antioxidant potential and consequent peroxidative damage in aquatic organisms (Di Giulio et al., 1989), an effective clear trend does not occur in environmental biomonitoring studies, because majority effects are reportedly chemical- or organ-dependent evaluated, and limited in exposure time (Martínez-Álvarez et al., 2005). Around this limitation on use biomarkers, and based in the results obtained, it seems to be true that at drought event, environmental drivers by itself, and in interaction with intrinsic parameters, such as physiological state, influence the ROS production and consequently the antioxidant defences in the brain of all fish studied species. Recently, some studies have identified the brain as a target organ in stressful conditions due to its high sensitivity to oxidative stress (Li et al., 2010; Mieiro et al., 2010), being well recognized that fish adapt to a variety of strategies to cooperate with fluctuations in environmental drivers (Hamilton et al., 2017), seem to play an important role in the induction of brain antioxidant defence system in the studied fish species. Our hypothesis assumes that in view of the adaptation of organisms to abnormal and extreme external conditions, an exposure induces the adaptive response that helps organisms to survive and recover. For example, in the cases of goldfish (Liza aurata), common carp (Cyprinus carpio) and medaka (Oryzias latipes), exposure to lower levels of dissolved oxygen increases SOD, CAT and GST activities (Lushchak et al., 2001; Lushchak, 2011; Oehlers et al., 2007, respectively) and the activity of GPx in the freshwater bivalve Corbicula fluminea (Vidal et al., 2002). Lushchak (2011) stated that when organisms exposed to oxygen deficiencies, the antioxidant potential increases to prevent the development of oxidative stress, being restored when the oxygen level is normalized (called the oxygen paradox). Many fish species use this anticipatory strategy, increasing the antioxidant capacity during oxygen fluctuations to be prepared for the effects from oxidative stress (e.g. Hermes-Lima and Zenteno-Savin, 2002; Lushchak et al., 2001).

The inductive mechanism of the brain antioxidant potential due to this environmental driver are not yet clearly established, however, it has been suggested that lower levels of oxygen lead to the reduction of carriers of electron transport chains; having more electrons to escape from the currents and to join with oxygen molecules, increasing ROS generation, consequently increasing antioxidant potential as an action to prevent and combat oxidative stress damage (Lushchak, 2011).

Also salinity fluctuations have been associated with increased ROS generation, but are not yet fully understood in fish, although the main osmoregulatory organs' functions, such as gills, kidneys have been intensively investigated (Liu et al., 2007). Less attention has been given to osmoregulation in brain of fish species (Sangiao-Alvarellos et al., 2003; Ogoshi et al., 2015), and although the role of enzymatic mobilization is not extensively yet known, our results seems to suggest that salinity stress in the cerebral metabolism leads to activation of antioxidant processes. Similar assumptions were recorded by Lavado et al. (2011) to Coho Salmon (Oncorhynchus kisutch), and by Liu et al. (2007) to the shrimp Litopenaeus vannamei, in vitro, stating that salinity changes increase SOD, CAT and GPx activities. Similarly, Choi et al. (2008) also exposed the flounder Paralichthys olivaceus to periodic salinity fluctuations, evaluating GPx and GST in brain as biomarkers of the antioxidant status, concluding that both enzymes play an important role in detoxification of ROS and therefore could serve as indicators of the response to oxidative stress face to salinity fluctuations.

It seems difficult to isolate the role of each environmental cue to oxidative stress on brain of fish species, being required more field research rather than in vitro studies. It is important that future studies should address the susceptibility of antioxidant defences of the brain to ROS production, generated by environmental drivers, reducing the degree of confusion when results are evaluated in environmental risk assessments.

The Mondego estuary basin is surrounded by a vast agriculture, aquaculture and other industrial areas (Ferreira dos Santos and Freitas, 2012), being reported in several local studies low - to moderate levels of metals (Coelho et al., 2006), PCBs (Baptista et al., 2013) and PCDD/ Fs (Nunes et al., 2011). Contrarily, Cruzeiro et al. (2016) found significant amounts of pesticides divided into 3 different categories (Fungicides - e.g. difenoconazole, PCB and HCB; Herbicides - e.g. alachlor; Insecticides - e.g. lindane, malathion, endosulfan, deltamethrin), several of them exceed the maximum values established by the European directives (98/83/EC and 2013/39/EU). Silva and Cerejeira (2015) pointed that in previous studies a quantitative evaluation of underestimated Mondego estuary toxicity may have been performed, reinforcing that combined effects of multiple chemical stressors is becoming a vital component of risk-based decisions aimed at protecting aquatic communities. Also Silva and Cerejeira (2015) stated the increase of pesticides and mixtures during periods of higher runoff, highlighting the risk of toxicity in fish community of the Mondego estuary.

So, given the contaminant uncertainty inherent in the Mondego estuarine area, a plausible explanation for the reduced enzymes' levels verified at the flood event seems to be an inhibition/depletion caused 
by an punctual increase of toxic substances, associated with the higher runoff in the Mondego estuary, where very high levels of precipitation were observed particularly in the central region of Portugal. It is worldwide known that climate change is projected to increase discharges of nutrients and contaminants in regions where extreme precipitation events occur (IPCC, 2007), increasing the probability of toxic interactions between biota and chemical compounds compared to normal environmental dynamics. According to the present results, depletion of enzymatic activity was previously found in the brain of several other fish species, such as Atlantic salmon (Berntssen et al., 2003), grey mullet (Mieiro et al., 2010), catfish (Hai et al., 1997), European eels and rainbow trout (Peña-Llopis et al., 2003), among others, after exposure to contaminants with high synergetic potential (e.g. endosulfan, dichlorvos, fenthion, vilogen, diocarbamates, dithiocarbamates, hexachloro-benzene). The highest sensitivity of the brain has been demonstrated after exposure to pesticides, noting reductions in the enzymatic activity of the studied enzymes, or even their inhibition (Song et al., 2006). The hypothesis that the brain may accumulate higher concentrations of contaminants compared to liver and muscle in some species, may contribute significantly to the increased risk of neurotoxicity associated with its high polyunsaturated fatty acids (PUFA) content, and making this organ more sensitive to oxidative damage (Ballesteros et al., 2009). Furthermore, this inhibitory responsive pattern has been shown to be organ-specific since both activities of these studied enzymes increase under influence of the same compounds in the liver and at the kidneys (e.g. Mieiro et al., 2010).

The positive correlation found among GR, GST and GPx reduced activities, represents a greater vulnerability of the studied fish brain to any kind of neurotoxic challenge at flood event, considering its wellknown interdependence, being the depletion of glutathione-dependent enzymes a signal of inability to counterbalance the ROS production.

\subsection{Peroxidative damage and its association with antioxidant defences}

Lipid peroxidation damage has been suggested as an additional mechanism by which oxidative stress exerts initial cellular and neurotoxic effects on mammals and fish (e.g. Berntssen et al., 2003). In this study at extreme drought event, the brain of D. labrax, P. flesus and $S$. solea, presented increased enzymatic levels (GR, GST, and GPx); theoretically, showing good ROS uptake and elimination of final products. Although our results suggested that GST and GPx have played a major role in detoxification, a worse physiological state and environmental drivers probably initiated a rapid and prolonged increase of ROS that was not effectively neutralized by the antioxidant defence system, failing to protect the brain against the lipid peroxidation, and ROS cleaning (Li et al., 2010; Lushchak, 2011). An additional explanation for the high values of antioxidant enzymes may have been a punctual synthesis "de novo", which was not sufficiently consistent to make a net increase in antioxidant defences (Lushchak et al., 2005). It is known that fluctuations in environmental drivers (salinity and dissolved oxygen) may cause oxidative damage through the induction of imbalance between ROS production and elimination (Lushchak, 2011), although plausible influence of contaminant load in the LPO levels cannot be discarded. Literature is also limited what concerns the influence of environmental drivers in the rate of contaminants incorporation into fish brain (Mieiro et al., 2010).

The general disaggregation in redox system was observed for the brain of D. labrax, P. flesus and S. solea, sampled in the Mondego estuary at the flood event, where higher precipitation and runoff may be associated with higher nutrient and contaminant load. The absence of a subsequently elevated LPO increase is intriguing. Lipid peroxidation measurements revealed that brains of fish species were able to cope with the pro-oxidant potential, despite the diminished portion in the enzymatic activities measured. These results are in agreement with some studies (see Ballesteros et al., 2009; Mieiro et al., 2010; Li et al., 2010), where there was little induction of LPO in the fish brain after exhaustion of the enzymatic antioxidants. A plausible explanation for this resistance seems to be related to the action of non-enzymatic antioxidants, such as cysteine, tocopherol and ascorbic acid, whose protective antioxidant role has already been demonstrated in fish and rat brain (Patra et al., 2001; Narra et al., 2015). Since in the flooding year, the organisms had optimal physiological status and high energy reserves, the significant presence of these non-enzymatic antioxidants seems plenty probable. Overall, our results are in accordance with Ahmad et al. (2006), who state that the increase in LPO cannot be predicted solely on the basis of a depletion of antioxidant enzymes. Although lipid peroxidation appears to have been avoided in brain cells, for the three fish species studied, in this year of severe flooding, the occurrence of oxidative damage in other crucial molecules such as DNA and proteins cannot be ruled out.

\section{Conclusion}

Severe climatic events affected the antioxidant defence system of a set of marine fish species, probably disturbing ecosystem sources, services and environmental drivers. Physiological indices are valuable tools, to complement the biochemical markers, providing a good reflection of the condition status of the organisms and serving to an initial screening of the occurrence of climate change events.

According to enzymatic activities of GR, GST and GPx, analyzed at the drought event, seems that environmental drivers play a key role in the induction of brain antioxidant defence system of seabass and flatfish species. A limited physiological condition, in association with an adaptation of the organisms face to fluctuations in environmental drivers, created a fast and prolonged increase of reactive oxygen species, counteracted by the evidenced elevation in the antioxidant potential; however, ROS has not been effectively neutralized by antioxidant system, failing in protection mechanisms and cause lipid damage.

Although the role of enzymatic mobilization on fish brains is not extensively yet known, our results suggested that the brain seems to be metabolically very sensitive to salinity and dissolved oxygen fluctuations, leading to activation of antioxidant processes, serving as indicators of the response to oxidative stress face to fluctuations in environmental drivers related to severe climatic events.

This study highlights the brain may be considered a good indicator and the enzymatic activity a good tool to detect the impact of climate events, due to the greater vulnerability of the brain proteins to degradation compared to lipids, and compared to other organs, such as liver or kidney.

\section{Acknowledgements}

Thanks are due for the financial support granted to CESAM (UID/ $\mathrm{AMB} / 50017$ ) and MARE (UID/MAR/04292/2013), to FCT/MEC through national funds, to the co-funding by the FEDER, within the PT2020 Partnership Agreement and Compete 2020, and to the Regional Operational ProgrammeCentro2020 within the scope of the Project Centro-01-0145-FEDER-000006. This research was also partially supported by PORBIOTA, E-Infrastructure Portuguese Information and Research in Biodiversity (POCI-01-0145-FEDER-022127), supported by Competitiveness and Internationalization Operational Programme and Regional Operational Programme of Lisbon, through FEDER, and by the Portuguese Foundation for Science and Technology (FCT), through national funds (OE). S. M. Marques and A. M. M. Gonçalves would like to acknowledge the financial support of FCT through the post-doctoral grants SFRH/BPD/112803/2015 and SFRH/BPD/97210/2013, respectively.

\section{References}

Agência Portuguesa do Ambiente 2013. Ministério do Ambiente, do Ordenamento do Território e do Desenvolvimento Regional. Available in http://www.iambiente.pt/ 
atlas/din/viewer.htm (accessed in September 2016).

Agência Portuguesa do Ambiente 2015. Ministério do Ambiente, do Ordenamento do Território e do Desenvolvimento Regional. Available in http://www.iambiente.pt/ atlas/din/viewer.htm (accessed in September 2016).

Ahmad, I., Maria, V.L., Oliveira, M., Pacheco, M., Santos, M.A., 2006. Oxidative stress and genotoxic effects in gill and kidney of Anguilla anguilla $\mathrm{L}$. exposed to chromium with or without pre-exposure to naphthoflavone. Mutat. Res./Genet. Toxicol. Environ. Mutagen. 608, 16-28.

Attrill, M.J., Power, M., 2000. Effects on invertebrate populations of drought-induced changes in estuarine water quality. Mar. Ecol. Prog. Ser. 203, 133-143.

Ballesteros, M.L., Wunderlin, D.A., Bistoni, M.A., 2009. Oxidative stress responses in different organs of Jenynsia multidentata exposed to endosulfan. Ecotoxicol. Environ. Saf. 72, 199-205.

Baptista, J., Martinho, F., Dolbeth, M., Viegas, I., Cabral, H.N., Pardal, M.A., 2010. Effects of freshwater flow on the fish assemblage of the Mondego estuary (Portugal): comparison between drought and non-drought years. Mar. Freshw. Res. 61, 490-501.

Baptista, J., Pato, P., Tavares, S., Duarte, A.C., Pardal, M.A., 2013. PCB bioaccumulation in three mullet species-a comparison study. Ecotoxicol. Environ. Saf. 94, 147-152.

Berntssen, M.H.G., Aatland, A., Handy, R.D., 2003. Chronic dietary mercury exposure causes oxidative stress, brain lesions, and altered behaviour in Atlantic salmon (Salmo salar). Aquat. Toxicol. 65, 55-72.

Birnie-Gauvin, K., Costantini, D., Cooke, S.J., Willmore, W.G., 2017. A comparative and evolutionary approach to oxidative stress in fish: a review. Fish Fish. 18, 928-942.

Bradford, M.M., 1976. A rapid and sensitive method for the quantitation of microgram quantities of protein utilizing the principle of protein-dye binding. Anal. Biochem. 72, 248-254.

Carlsberg, Mannervik, B., 1985. Glutathione reductase. Methods Enzymol. 113, 484-490.

Clarke, K.R., Gorley, R.N., 2006. PRIMER V6: user manual-tutorial. Marine Laboratory, Plymouth.

Coelho, J.P., Pimenta, J., Gomes, R., Barroso, C., Pereira, M.E., Pardal, M.A., Duarte, A.C., 2006. Can Nassarius reticulatus be used as a bioindicator for $\mathrm{Hg}$ contamination? Results from a longitudinal study of the Portuguese coastline. Mar. Pollut. Bull. 52, 674-680.

Choi, C.Y., An, K.W., An, M.I., 2008. Molecular characterization and mRNA expression of glutathione peroxidase and glutathione S-transferase during osmotic stress in olive flounder (Paralichthys olivaceus). Comp. Biochem. Physiol. Part A: Mol. Integr. Physiol. A 149, 330-337.

Correia, A.D.M.H., Costa, O.J., Luis, D.R., Livingstone,, 2003. Age-related changes in antioxidant enzyme activities, fatty acid composition and lipid peroxidation in whole body Gammarus lacusta (Crustacea: Amphipoda). J. Exp. Mar. Biol. Ecol. 289, 83-101.

Cruzeiro, C., Rocha, E., Pardal, M.A., Rocha, M.J., 2016. Environmental assessment of pesticides in the Mondego River Estuary (Portugal). Mar. Pollut. Bull. 103, 240-246.

Di Giulio, R.T., Washburn, P.C., Wenning, R.J., Winston, G.W., Jewell, C.S., 1989. Biochemical responses in aquatic animals: a review of determinants of oxidative stress. Environ. Toxicol. Chem. 8, 1103-1123.

Dolbeth, M., Martinho, F., Viegas, I., Cabral, H., Pardal, M.A., 2008. Estuarine production of resident and nursery fish species: Conditioning by drought events? Estuar. Coast. Shelf Sci. 78, 51-60.

Dolbeth, M., Cardoso, P., Grilo, T., Raffaelli, D., Pardal, M.A., 2013. Drivers of estuarine benthic species distribution patterns following a restoration of a seagrass bed: a functional trait analyses. Mar. Pollut. Bull. 72, 47-54.

Dringen, R., 2000. Metabolism and functions of glutathione in brain. Prog. Neurobiol. 62, 649-671.

Eastwood, S., Couture, P., 2002. Seasonal variations in condition and liver metal concentrations of yellow perch (Perca flavescens) from a metal-contaminated environment. AquaticToxicology 58, 43-56.

Ferraro, L., Tomasini, M., Tanganelli, S., Mazza, R., 2009. Developmental exposure to methyl-mercury elicits early cell death in the cerebral cortex and long-term memory deficits in the rat. Int. J. Dev. Neurosci. 27, 165-174.

Ferreira dos Santos, J., Freitas, V., 2012. Aproveitamento hidroagrícola do Baixo Mondego-actualidade e desafios futuros. In: aph (Ed.), IV Congresso nacional de rega e drenagem. Direcção-Geral de Agricultura e Desenvolvimento Rural (DGADR), p. 14 Coimbra, Portugal.

Flohé, L., Günzler, W.A., 1984. Assays of glutathione peroxidase. Methods Enzymol. 105, 114-120.

Gonçalves, A.M.M., Barroso, D.V., Serafim, T.L., Verdelhos, T., Marques, J.C., Gonçalves, F., 2017. The biochemical response of two commercial bivalve species to exposure to strong salinity changes illustrated by selected biomarkers. Ecol. Ind. 77, 59-66.

Gonçalves, A.M.M., Pardal, M.A., Marques, S.C., Mendes, S., Fernández-Gómez, M.J., Galindo-Villardón, M.P., Azeiteiro, U.M., 2012. Response to Climatic variability of Copepoda life history stages in a southern European temperate estuary. Zool. Stud. 51, 321-335.

Grilo, T.F., Cardoso, P.G., Dolbeth, M., Bordalo, M.D., Pardal, M.A., 2011. Effects of extreme climate events on the macrobenthic communities' structure and functioning of a temperate estuary. Mar. Pollut. Bull. 62, 303-311.

Habig, W.H., Pabst, M.J., Jakoby, W.B., 1974. Glutathione S-transferases the first enzymatic step in mercapturic acid formation. J. Biol. Chem. 249, 7130-7139.

Hai, D.Q., Varga, S.I., Matkovics, B., 1997. Organophosphate effects on antioxidant system of carp (Cyprinus carpio) and catfish (Ictalurus nebulosus). Comparative biochemistry and physiology. Part C, Pharmacol., Toxicol. Endocrinol. 117, 83-88.

Hamilton, P.B., Rolshausen, G., Webster, T.M.U., Tyler, C.R., 2017. Adaptive capabilities and fitness consequences associated with pollution exposure in fish. Philos. Trans. R. Soc. B 3722, 20160042.

Hellou, J., Ross, N.W., Moon, T.W., 2012. Glutathione, glutathione S-transferase, and glutathione conjugates, complementary markers of oxidative stress in aquatic biota.
Environ. Sci. Pollut. Res. 19, 2007-2023.

Hermes-Lima, M., Zenteno-Savin, T., 2002. Animal response to drastic changes in oxygen availability and physiological oxidative stress. Comp. Biochem. Physiol. C: Toxicol. Pharmacol. 133, 537-556.

Hooper, M.J., Ankley, G.T., Cristol, D.A., Maryoung, L.A., Noyes, P.D., Pinkerton, K.E., 2012. Interactions between chemical and climate stressors: a role for mechanistic toxicology in assessing climate change risks. Environ. Toxicol. Chem. 32, 32-48.

Huang, C.F., Hsu, C.J., Liu, S.H., Lin-Shiau, S.Y., 2008. Neurotoxicological mechanism of methylmercury induced by low-dose and long-term exposure in mice: oxidative stress and down-regulated $\mathrm{Na}+/ \mathrm{K}+$-ATPase involved. Toxicol. Lett. 176, 188-197.

IPCC, 2007. Climate Change 2007: Synthesis Report. Contribution of Working Groups I, II, and III tothe Fourth Assessment Report of the Intergovernmental Panel on Climate Change. Geneva, Switzerland.

IPCC, 2007b. Climate Change 2007: Impacts, Adaptation, and Vulnerability. Contribution of Working Group II to the Fourth Assessment Report of the Intergovernmental Panel on Climate. Change. Cambridge University Press, Cambridge, UK.

Kleinkauf, A., Connor, L., Swarbreck, D., Levene, C., Walker, P., Johnson, P.J., 2004. General condition biomarkers in relation to contaminant burden in European flounder (Platichthys flesus). Ecotoxicol. Environ. Saf. 58, 335-355.

Kopecka, J., Pempkowiak, J., 2008. Temporal and spatial variations of selected biomarker activities in flounder (Platichthys flesus) collected in the Baltic proper. Ecotoxicol. Environ. Saf. 70, 379-391.

Lavado, R., Maryoung, L.A., Schlenk, D., 2011. Hypersalinity acclimation increases the toxicity of the insecticide phorate in coho salmon (Oncorhynchus kisutch). Environ. Sci. Technol. 45, 4623-4629.

Li, Z.H., Zlabek, V., Velisek, J., Grabic, R., Machova, J., Randak, T., 2010. Modulation of antioxidant defence system in brain of rainbow trout (Oncorhynchus mykiss) after chronic carbamazepine treatment. Comp. Biochem. Physiol. C: Toxicol. Pharmacol. $151,137-141$.

Liu, Y., Wang, W.N., Wang, A.L., Wang, J.M., Sun, R.Y., 2007. Effects of dietary vitamin E supplementation on antioxidant enzyme activities in Litopenaeus vannamei (Boone, 1931) exposed to acute salinity changes. Aquaculture 265, 351-358.

Lloret, J., de Sola, L.G., Souplet, A., Galzin, R., 2002. Effects of large-scale habitat variability on condition of demersal exploited fish in the north-western Mediterranean. ICES J. Mar. Sci.: J. du Conseil 59, 1215-1227.

Lushchak, V.I., 2011. Environmentally induced oxidative stress in aquatic animals. AquaticToxicology 101, 13-30.

Lushchak, V.I., Bagnyukova, T.V., Lushchak, O.V., Storey, J.M., Storey, K.B., 2005. Hypoxia and recovery perturb free radical processes and antioxidant potential in common carp (Cyprinus carpio) tissues. Int. J. Biochem. Cell Biol. 37, 1319-1330.

Lushchak, V.I., Lushchak, L.P., Mota, A.A., Hermes-Lima, M., 2001. Oxidative stress and antioxidant defenses in goldfish Carassius auratus during anoxia and reoxygenation. Ecotoxicol. Environ. Saf. 280, 100-107.

Martinho, F., Leitão, R., Neto, J.M., Cabral, H.N., Marques, J.C., Pardal, M.A., 2007. The use of nursery areas by juvenile fish in a temperate estuary, Portugal. Hydrobiologia 587, 281-290.

Martinho, F., Nyitrai, D., Crespo, D., Pardal, M.A., 2015. Efficacy of single and multimetric fish-based indices in tracking anthropogenic pressures in estuaries: an 8-year case study. Mar. Pollut. Bull. 101, 153-162.

Martínez-Álvarez, R.M., Morales, A.E., Sanz, A., 2005. Antioxidant defenses in fish: biotic and abiotic factors. Rev. Fish Biol. Fish. 15, 75-88.

Mieiro, C.L., Ahmad, I., Pereira, M.E., Duarte, A.C., Pacheco, M., 2010. Antioxidant system breakdown in brain of feral golden grey mullet (Liza aurata) as an effect of mercury exposure. Ecotoxicology 19, 1034-1045.

Narra, M.R.K., Rajender, R., Rudra Reddy, J.V., Rao, G. Begum, 2015. The role of vitamin $\mathrm{C}$ as antioxidant in protection of biochemical and haematological stress induced by chlorpyrifos in freshwater fish Clarias batrachus. Chemosphere 132, 172-178.

Nunes, M., Marchand, P., Vernisseau, A., Le Bizec, B., Ramos, F., Pardal, M.A., 2011. PCDD/Fs and dioxin-like PCBs in sediment and biota from the Mondego estuary (Portugal). Chemosphere 83, 1345-1352.

Oehlers, L.P., Perez, A.N., Walter, R.B., 2007. Detection of hypoxia-related proteins in medaka (Oryzias latipes) brain tissue by difference gel electrophoresis and de novo sequencing of 4-sulfophenyl isothiocyanate-derivatized peptides by matrix-assisted laser desorption/ionization time-of-flight mass spectrometry. Comp. Biochem. Physiol. C: Toxicol. Pharmacol. 145, 120-133.

Ogoshi, M., Kato, K., Sakamoto, T., 2015. Effect of environmental salinity on expression of adrenomedullin genes suggests osmoregulatory activity in the medaka, Oryzias latipes. Zool. Lett. 1, 12.

Oliva, M., José Vicente, J., Gravato, C., Guilhermino, L., Dolores Galindo-Riaño, M., 2012. Oxidative stress biomarkers in Senegal sole, Solea senegalensis, to assess the impact of heavy metal pollution in a Huelva estuary (SW Spain): Seasonal and spatial variation. Ecotoxicol. Environ. Saf. 75, 151-162.

Pain, S., Devin, S., Parant, M., 2007. Biomarker versus environmental factors: seasonal variations and modelling multixenobiotic defence (MXD) transport activity in transplanted zebra mussels. Sci. Total Environ. 373, 103-112.

Patra, R.C., Swarup, D., Dwivedi, S.K., 2001. Antioxidant effects of a tocopherol, ascorbic acid and 1-methionine on lead induced oxidative stress to the liver, kidney and brain in rats. Toxicology 162, 81-88.

Peña-Llopis, S., Fernando, M.D., Peña, J.B., 2003. Fish tolerance to organophosphateinduced oxidative stress is dependent on the glutathione metabolism and enhanced by N-acetylcysteine. Aquat. Toxicol. 65, 337-360.

Pottinger, T.G., Carrick, T.R., Yeomans, W.E., 2002. The three-spined stickleback as an environmental sentinel: effects of stressors on whole-body physiological indices. J. Fish Biol. 61, 207-229.

Sangiao-Alvarellos, S., Laiz-Carrión, R., Guzmán, J.M., del Río, M.P.M., Miguez, J.M., Mancera, J.M., Soengas, J.L., 2003. Acclimation of S. aurata to various salinities 
alters energy metabolism of osmoregulatory and non-osmoregulatory organs. Am. J. Physiol.-Regul., Integr. Comp. Physiol. 285, 897-907.

Sheehan, D., Power, A., 1999. Effects of seasonality on xenobiotic and antioxidant defence mechanisms of bivalve molluscs. Comp. Biochem. Physiol. C: Pharmacol. Toxicol. Endocrinol. 123, 193-199.

Silva, E., Cerejeira, M.J., 2015. Concentration addition-based approach for aquatic risk assessment of realistic pesticide mixtures in Portuguese river basins. Environ. Sci. Pollut. Res. 22, 6756-6765.

Soengas, J.L., Aldegunde, M., 2002. Energy metabolism of fish brain. Comp. Biochem. Physiol. B: Biochem. Mol. Biol. 131, 271-296.

Song, S.B., Xu, Y., Zhou, B.S., 2006. Effects of hexachloro-benzene on antioxidant status of liver and brain of the common carp (Cyprinus carpio). Chemosphere 65, 699-706.
Ter Braak, C. J., 1995. "Ordination,” in Data Analysis in Community and Landscape Ecology eds R. H. Jongman C. J. Ter Braak and O. F. van Tongeren (Cambridge: Cambridge University Press) 91-173.

Van der Oost, R., Beyer, J., Vermeulen, N.P., 2003. Fish bioaccumulation and biomarkers in environmental risk assessment: a review. Environ. Toxicol. Pharmacol. 13, 57-149.

Veríssimo, H., Bremner, J., Garcia, C., Patrício, J., van der Linden, P., Marques, J.C., 2012. Assessment of the subtidal macrobenthic community functioning of a temperate estuary following environmental restoration. Ecol. Ind. 23, 312-322.

Vidal, M.L., Bassères, A., Narbonne, J.F., 2002. Influence of temperature, pH, oxygenation, water-type and substrate on biomarker responses in the freshwater clam Corbicula fluminea (Müller). Comp. Biochem. Physiol. Part C: Toxicol. Pharmacol. 132, 93-104. 